\title{
KERJA BAKTI SETIAP MESJID DAN INSTANSI
}

(KELURAHAN BONTOTANGNGA KEC.TAMALATEA)

NAMA : ADELIA AHMAD

NIM $\quad: 1915349021008$

EMAIL : adeliaahmad@gmail.com

\section{A. KERJA BAKTI SETIAP MESJID}

\section{Bentuk Kegiatan}

- Membersihkan Masjid Besar Kelurahan Bontotangnga

2. Lokasi

- Lingkungan Bontotangnga

- Lingkugan Borong Tammatea

- Lingkungan Sangingloe

- Lingkugan Bumbungloe

- Lingkungan Tanetea

- Lingkungan Mannuruki

- Lingkungan Sarroanging

- Lingkungan Bungung Lompoa

- Lingkungan Pammanjengang

\section{Hari Tanggal Dan Waktu}

- Setiap Hari Jumat, Tanggal 25 September 2020/ Pukul 08.00-10.30 Wita Sampai Tanggal 09 Oktober 2020

\section{Peserta Yang Dilibatkan}

- Mahasiswa KKLP YAPTI JENEPONTO

\section{Alasan Yang Diadakannya}

- Karena melihat keadaan Masjid yang kotor dan akan dilaksanakan sholat jumat maka kami para mahasiswa berinisiatif membersihkan mesjid tersebut, berhubung karena adanya wabah Covid-19 maka diadakan penyemprotan desinfektan. 


\section{Tujuan Dan Manfaat}

- Untuk meningkatkan kenyamanan masyarakat kelurahan bontotangnga dalam beribadah dan memutus rantai penyebaran Covid-19.

\section{Deskripsi Kegiatan}

Kegiatan ini dilakukan dimulai dari membersihkan area dalam Masjid sampai pekerangannya di pagi hari, sebelum dilaksanakannya Sholat jumat agar masyarakat nyaman melaksanakan Sholat berjamaah.

\section{B. Instansi}

\section{Bentuk Kegiatan}

- Kerja bakti disetiap masjid dan instansi

\section{Lokasi}

- Kantor lurah Bontotangnga

- Kantor kecamatan

- Masjid di kel. Bontotangnga

\section{Hari Tanggal Dan Waktu}

- Hari Minggu, 11 Oktober 2020/ Pukul 08.00-10.30 Wita.

\section{Peserta Yang Dilibatkan}

- Mahasiswa KKLP YAPTI JENEPONTO

- Anggota koramil, dan

- $\quad$ Staff kecamatan

\section{Alasan Yang Diadakannya}

- Instansi lebih bersih dan mendapat nilai plus dari beberapa instansi dan masyarakat yang melihat.

\section{Tujuan Dan Manfaat}

- Untuk meningkatkan pentingnya kebersihan linkungan sehingga suasana dikantor atau tempat kerja akan terasa nyaman dan terpelihara dengan baik.

\section{Deskripsi Kegiatan}

Mahasiswa KKLP YAPTI JENEPONTO bersama- sama mengadakan kerja bakti pada hari minggu pagi. 